\title{
TEACHING VOCABULARY TO YOUNG LEARNER USING VIDEO ON YOUTUBE AT ENGLISH COURSE
}

\author{
Tira Chairiah Hariyono ${ }^{1}$ \\ Faculty of Teacher Training and Education ${ }^{1}$ \\ Ibn Khaldun University Bogor \\ chairiahtira@gmail.com
}

APA Citation: Hariyono, T. C. (2020). Teaching vocabulary to young learner using video on YouTube at English course. Language Research in Society, 1(1), 41-46.

\begin{abstract}
Vocabulary is one of the important elements of the English language. There are many media which can be used in teaching vocabulary to young learners. In this research, the researcher used video on YouTube to teach vocabulary. The research focuses on how students' engagement during the implementation of video on YouTube in teaching vocabulary at an English course. In this research, the researcher used descriptive-qualitative research, and observation and documentation were used for collecting the data. This research was conducted at an English course in Bogor, in which the participants are seven young learners at grade two. The findings of this research were classified into two themes; students' response to the classroom activities and the teacher instruction, and student's engagement to the use of video on YouTube. It is revealed that most young learners at an English course were engaged during the implementation of the video on YouTube in teaching vocabulary. They also gave positive responses to the learning activity and preferred learning English vocabulary by using video on YouTube.
\end{abstract}

Keywords: vocabulary; young learner; learning vocabulary through video.

\section{INTRODUCTION}

English is the most widely used communication tool in various countries where English is also often referred to as an international language, therefore, we need to learn English. In learning English, four major skills must be mastered, namely listening, speaking, reading, and writing. Students need English vocabulary to support them in these skills and by having a lot of English vocabulary they would be able to communicate in spoken and written English. Rahmadhani (2015) stated that young learners should have been taught vocabulary early because it is an important item in language learning.

Syafrizal and Haerudin (2018, p. 41-42) outline that "Vocabulary can be defined, roughly, as the words we teach in the foreign language. However, a new item of 42 vocabulary may be more than just a single word: for example, post office, and mother-in-law, which are made up of two or three words but express a single idea". One of the principles in learning vocabulary as Flanigan (2015) expressed we became an expert when we find a new vocabulary which does not know the meaning. After we know that, we will use it frequently. Vocabulary is a critical element in a language. As claimed by Rahmadhani (2015), the main aspect of language skills is vocabulary which can support students' ability to the four skills in a language (speaking, listening, reading and writing). Besides, Thornbury (2002, p. 13) said: "Without grammar very little can be conveyed, without vocabulary, nothing can be conveyed".

Also, the learner will easily understand a word if they comprehend better about that vocabulary. Therefore, students need to improve and understand vocabulary in a language (Lelawati et al., 2018). When the learner can understand the word well, they would be easier to communicate in 
written or spoken English. Furthermore, Al qahtani (2015, p. 22) stated "The relationship between vocabulary knowledge and language use as complementary: knowledge of vocabulary enables language use and, conversely, language use leads to an increase in vocabulary knowledge". This means they have a correlation between them which cannot be separated. Also, the role of a teacher who provides knowledge about vocabulary and how to use it in daily life is an important thing in teaching vocabulary to the students. Teachers must have knowledge of vocabulary which should cover the form, the meaning and the use of the word. However, teaching vocabulary to young learners is not as easy as we think it would be different from teaching vocabulary to teenagers and adults. It is because young learners have their characteristic. Syafrizal and Haerudin (2018) expressed that, rather than adults, young learners show more intense and eager enjoyment, energetic, and easier to adjust in particular circumstance.

Syafrizal and Haerudin (2018, p. 42) claimed that "The young learners are students who are studying in Elementary or Senior High School aging 7-15 and they studied English as a second language". Moreover, the mastery of grammar, pronunciation, and vocabulary develops when young learners are around four or five years old, also during this period, young learners develop a vocabulary that is interesting to them (Gordon, 2007). In the proses learning, young learners have various ways of learning such as understanding a meaning based on their experience and explore it and try something new because it has a great curiosity (Juhana, 2014). Teaching for young learners has a different way to teach adults. Besides differences of age, also differences between what they need and their understanding. In line with that, (Rahmadhani, 2015) "to be successful in teaching children in a second and foreign language, it requires specific skills and intuitions that are different from those appropriate for teaching adults". The role of teachers who use the video on YouTube in the teaching process, it must match the video content to the subject matter in accordance with the child's ability (Nasution, 2019).

Even though they still have a problem in learning English vocabulary such as; the lack of experience of the language thus affecting the number and the type of language they know (Lutviana \& Mafulah, 2017), they can lose interest in learning, and also (Juhana, 2014) said they get bored easily, so the center of learning is highly short. Therefore, teachers should know the factors in teaching, such as method, strategies, technique, and material that can be used, Especially, in teaching young learners which can increase their interest in learning. (Lelawati et al., 2018; Rahmadhani, 2015) claimed a good method does not work if the teacher did not know how to use it and a good teacher would not be effective if the method which she/he chooses is not suitable. Using video on YouTube can create an atmosphere in the learning process more enjoyable and meaningful, so learners are easier to remember the material (Almurashi, 2016; Juhana, 2014). Moreover, young learners can build their meaningful usnderstanding based on the objects they see and hear or when they touch and interact directly with these objects (Juhana, 2014). As we know, the video presents language in real terms because the video has visual and audio features. It can help young learners to convey the meaning of vocabulary and attract their interest in learning vocabulary.

The study of Zaidi et al. (2018) explained university students are interested in using YouTube. Also, it helps them with their assignments. In line with that, Kabooha and Elyas (2015) expressed their result of study such as the students have a positive response on using YouTube and give effect in their vocabulary acquisition. Many studies have examined the use of technology in teaching and learning. One of the technologies that can be used is the videos on YouTube. Riswandi (2016) defined YouTube as a video-sharing website in which users can upload, share and view videos. Using video in the learning process helps students because it can explain all fields of knowledge and interest and the attention of students (Kabooha \& Elyas, 2015). 
Also, the use of YouTube can make learning becomes fun with it offers the subject matter, which is packed with creativity as possible. Videos can positively influence education which access is very fast and fun, the existence of culture-based videos, and languages from around the world. In other words, learning through YouTube can change the learning environment positively (Almurasih, 2016). Also, YouTube can make the students more interactive because it would be easier to find a topic and new vocabulary (Riswandi, 2016).

Based on these statements, the writer conducted a study to observe how young learners were engaged during the implementation of video on YouTube in teaching vocabulary at an English course.

\section{METHOD}

In this study, this qualitative research was applied by descriptive research to investigate how young learners were engaged during the implementation of video on YouTube in teaching vocabulary at an English course. The descriptive method is used to present a broad range of research that has a general-purpose to describe the situation of the event. Therefore, the method was used in this research because the researcher wanted to describe the engagement of students at an English course during the implementation of video in teaching vocabulary.

\section{Setting and Participants}

The research was carried out at one of the English courses in Bogor. The reason for choosing young learners at an English course because the researcher assumes, they have more experience than other students in the learning process. The participants in this study were seven young learners who are in the second level class where they were seven years old and the researcher as a teacher who taught English vocabulary.

\section{Data Collection and Data Analysis}

The instrument used for collecting the data is observation and documentation. The researcher observed the entire process of teaching-learning activity and used observation to see the students' vocabulary achievement in the ongoing process of treatment of qualitative design. According to Creswell (2012), Observation is the process of gathering open-ended, first-hand information by observing people and places at a research. To get the data, researcher was took a part in activities in the setting researcher observe.

After collecting the data from the observed teaching-learning activity, the data were analyzed qualitatively to find how students engage in the activity. Creswell (2012) stated the type of data from observations are fieldnotes and drwing. Observation data analyzed by paying attention to the situation while in class and classification into several items observed and then the result will be described by statements which seen and felt.

\section{FINDINGS \& DISCUSSION}

This part presents the finding of the research which the researcher found by doing observation and then classifying the result into two themes, such as:

\section{Students' response to the classroom activities and the teacher instruction}

In the first theme, the researcher found that students had a positive response in teaching and learning activities in the classroom, that can be seen from their attending the classes at this course. In addition, in the teaching and learning process, learners tend to be involved in these activities. They always answer questions from the teacher about "the things in my bedroom, living room, etc." which is conducted during six meetings based on the learning material in the module or book. Even though only four learners answer the question by expressing "Miss, I 
want to answer question number three because it is easy "or " I have not given up, Miss. Let me think first, miss "and three other learners only know the word in the Indonesian language (their first language) like" "Miss, in my bedroom, there are a fan and also AC, but I don't know how to say them in English". On the other said, when they said "Miss, in my bedroom" it shows us that they are easier to answer questions based on what is happening within themselves.

Juhana (2014) said that "young learners are keen to talk about themselves, and respond well to learning that uses themselves and their own lives as main topics in the classroom and the like". For that reason, it proves that students are involved in in-class activities by answering all the teacher's questions or from the responses they express about objects in a room. Moreover, this study shows that students interact well with their teachers especially for teacher's instruction like they come to the front of the class to write their answers on the board and interact well with other learners. They interact by helping to directly spell words from the vocabulary list on the board to make the other learners are easier to answer the question. Jazuly and Indrayani (2018) claimed the best technique in any class is asking and question techniques.

Therefore, to learner interaction illustrated from the results of observations, researchers also found that the learners were eager to ask questions. They did it by raising their hands and always asking the teacher about the pronunciation to a word and often ask "Miss, how to say cupboard in English?". When there is doubt, they always ask questions, such as expressing "is the chair included in an object in the kitchen?". Juhana (2014, p. 45) stated that "young learners learn by thinking in term of theme". When there is still some vocabulary that they have not answered, then the teacher gives a video watch on YouTube that was previously prepared by the teacher and ensures that the video is related to the material being studied.

Frequently, learners directly say "Miss, I just saw in the video, the clock in English is a clock, I think it's eklok". That expression showed that students appeared to understand the vocabulary after they see the video. Also, when they watching the video, they got the correct spelling word and how the shape of the object is. The teacher will ask them one by one to make sure their understanding of the material before they go home. The questions are around the video story, vocabularies which they got when watching the video. Students enthusiastically raised their hands to answer questions, but there are children who directly answered without raised their hands.

\section{Student's engagement to the use of video on YouTube}

On the second theme, researchers found that the learners were engaged in the lesson using technology. That can be seen when the teacher starts the video on YouTube, learners focus on looking at the laptop screen and occasionally laugh when there is a funny part. They always express it directly like saying "haha, he runs so cute Miss, like my sister" or feeling sad like "so poor children left in the forest" besides that they also asked questions several times like "why are they left in the forest?, Miss they can make it from wood, wow amazing ". As (Juhana, 2014) said having a high curiosity is one of the characteristics of young learners where they always try things they have never gotten and explore them. evident from the various expressions available, illustrate that learners often ask "why can it be like that, miss?" where their curiosity arises when watching videos.

As for the use of videos on YouTube in teaching vocabulary to young learners, the discovery that the students got excited using videos on YouTube in the classroom. When the teacher asks the learners "are you happy watching the video?" and directly they say "sure Miss, Lafla so happy". Besides expressions like that, some students often ask "Miss tomorrow we watch again, okay Miss, please?". Kabooha and Elyas (2015) stated the benefits of using YouTube in the classroom could develop vocabulary, make learning fun and interesting, and also motivate learners. Where in the teaching of young learners is very important for us to have strategies that 
can facilitate and increase their learning motivation. As (Juhana, 2014) said young learners easily feel bored in their long study routines and their attention tends to be short.

other findings such as the students feel that using technology is very helpful to support the learning process. The use of video is very useful for learning "Miss, I am more enthusiastic" from this expression. It can be seen that the use of YouTube enhances the positive atmosphere in learning activities. In addition, students spontaneously mention the random vocabulary they hear and see "when, please, and I remember yesterday we watch the old clock ". besides increasing the vocabulary, they have, it also teaches them about the shape of an object that they have never seen before. In line with that, (Abdulrahman Almurashi, 2016) watching videos can make the classroom more fun and meaningful, increase learners' insights and information with experiences that are presented in the video, and also increase their fluency in using simple expressions using English.

From the research findings have an impact toward teaching practice for English teachers. The teacher must understand how to teach using technology for young learner by paying attention to some characteristic of young learner. Also, teacher creativity can increase by using video on YouTube in explaining the material.

\section{CONCLUSION}

This research was carried out at the grade two in an English language course, Bogor. The research participants involved were seven young students. Researchers focus on how students are involved in teaching vocabulary using videos on YouTube. The researchers' findings are presented in two themes: student responses to classroom activities and teacher instructions and student involvement in the use of videos on YouTube. In the first theme, it was found that students have positive responses in teaching and learning activities, young learners have interaction with the teacher and other students, were eager to ask questions, and using videos on YouTube makes it easier for students to understand vocabulary.

On the second theme in the student's engagement with the use of video on YouTube sessions, the researchers found that the students got excited using videos on YouTube in the classroom, because they felt happy, motivated, and the classroom atmosphere became fun. Moreover, the students were engaged in the lesson using technology and the students feel that using technology is very helpful to support the learning process. During the observation day 1 until day6, learning that is done is about English vocabulary about things at home. The result of the observation shows that most young learners at an English course were engaged during the implementation of the video on YouTube in teaching vocabulary. Based on the result of this study, the researcher has some suggestion; to the English teacher, should be creative and able to vary their technique in teaching language and for the learner, through video is one way to improve English vocabulary. The students should always practice use English vocabulary.

\section{REFERENCES}

Almurashi, W.A. (2016). The effective use of YouTube videos for teaching English language in classrooms as supplementary material at Taibah university in alula. International Journal of English Language and Linguistics Research, 4(3), 32-47. http://www.eajournals.org/wp-content/uploads/The-Effective-Use-of-Youtube-Videosfor-Teaching-English-Language-in-Classrooms-as-Supplementary-Material-at-TaibahUniversity-in-Alula.pdf

Al qahtani, M. (2015). The importance of vocabulary in language learning and how to be taught. International Journal of Teaching and Education, 3(3), 21-34. https://doi.org/10.20472/te.2015.3.3.002 
Creswell, J. W. (2012). Educational research: planning, conducting and evaluating quantitative and qualitative research. Pearson.

Flanigan, K. (2015). Building a Better Vocabulary. The Teaching Company. https://doi.org/10.1126/science.1172136

Gordon, T. (2007). Teaching Young Children a Second Language. Praeger Publishers. https://doi.org/10.2167/lcc017b.0

Jazuly, A., \& Indrayani, N. (2018). Guidance of teaching English to young learner (TEYL) for early childhood education teachers at ad Dhuha kindergarten of Jember. Linguistic, English Education and Art (LEEA) Journal, 1(2), 168-179. https://doi.org/10.31539/leea.v1i2.175

Juhana. (2014). Teaching English to Young Learners: Some Points to be Considered. Asian Journal of Education and E-Learning, 02(01), 43-46. www.ajouronline.com

Kabooha, R., \& Elyas, T. (2015). The impacts of using YouTube videos on learning vocabulary in Saudi EFL classroom. ICERI2015 Conference, December 2016, 3525-3531. https://www.researchgate.net/publication/283153582_THE_IMPACTS_OF_USING_YO UTUBE_VIDEOS_ON_LEARNING_VOCABULARY_IN_SAUDI_EFL_CLASSROO MS

Lelawati, S., Dhiya, S., \& Mailani, P. N. (2018). The teaching of English vocabulary to young learners. PROJECT (Professional Journal of English Education), 1(2), 95-100.

Lutviana, R., \& Mafulah, S. (2017). The use of video and total physical response (TPR) to improve students' vocabulary mastery. EnJourMe (English Journal of Merdeka) : Culture, Language, and Teaching of English, 2(2), 89-97. https://doi.org/10.26905/enjourme.v2i2.1970

Nasution, A. K. R. (2019). YouTube as a media in English language teaching (ELT) context: Teaching procedure text. Utamax : Journal of Ultimate Research and Trends in Education, 1(1), 29-33. https://doi.org/10.31849/utamax.v1i1.2788

Rahmadhani, P. A. (2015). Techniques in teaching vocabulary to young learners at LIA english course. TELL-US Journal, 1(2), 1-8.

Riswandi, D. (2016). Use of YouTube-based videos to improve students' speaking skill. Proceeding The 2nd International Conference On Teacher Training and Education, 2(1), 269. https://jurnal.uns.ac.id/ictte/article/view/8150

Syafrizal, S., \& Haerudin, H. (2018). The implementation of vocabulary building strategy in teaching English vocabulary to young learners. Journal of English Language Teaching, 5(1), 40-48. http://ojs.ikipmataram.ac.id/index.php/joelt

Thornbury, S. (2002). How to teach vocabulary. Pearson educational.

Zaidi, A., Awaludin, F. A., Karim, R. A., Ghani, N. F. C., Rani, M. S. A., \& Ibrahim, N. (2018). University students' perceptions of YouTube usage in (ESL) classrooms. International Journal of Academic Research in Business and Social Sciences, 8(1), 541-553. https://doi.org/10.6007/ijarbss/v8-i1/3826 